\title{
DINAMIKA SISTEM EKONOMI SIRKULAR BERBASIS MASYARAKAT METODE CAUSAL LOOP DIAGRAM KOTA BENGKAYANG
}

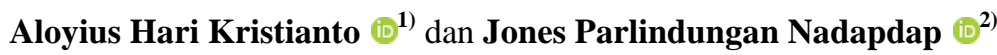 \\ 1) Ilmu Ekonomi, Pasca Sarjana Universitas Tanjungpura \\ ${ }^{2)}$ Manajemen, Institut Shanti Bhuana \\ ${ }^{1}$ Jl.Imam Bonjol, Pontianak 78124 \\ ${ }^{2}$ Jl. Bukit Karmel 1, Bengkayang 79211 \\ E-mail : aloysius.hari@shantibhuana.ac.id ${ }^{1)}$,jones.parlindungan@shantibhuana.ac.id ${ }^{2)}$
}

\begin{abstract}
ABSTRAK
Ekonomi sirkular merupakan sebuah konsep ekonomi yang mengimplementasikan tujuan pembangunan berkelanjutan yang terkait dengan tingkat konsumsi dan produksi yang bertanggung jawab dan berkelanjutan. Konsep ekonomi ini memberikan sebuah solusi dari permasalahan sampah yang diproduksi oleh masyarakat, dengan tujuan membuat produk baru dari sumber daya sampah yang bermanfaat dan bernilai ekonomi. Tujuan penelitian ini adalah mengidentifikasi permasalahan tata kelola sampah dalam kontribusi terhadap perekonomian daerah dan lingkungan hidup. Metode penelitian yang dipergunakan adalah metode kualitatif dinamika sistem (system dynamics) pendekatan Causal Loop Diagram. Teknik analis data dengan menggunakan metode triangulasi yaitu wawancara mendalam dengan key informan, observasi partisipasi dan dokumentasi. Masih perlunya waktu secara bertahap (delay time) dalam mengimplementasikan konsep ekonomi sirkular berbasis masyarakat di Kota Bengkayang terutama terkait dengan change behavior. Perlu adanya tindakan kolaboratif antar stakeholder seperti masyarakat umum, pemerintah daerah, pengusaha dan aktivis lingkungan hidup dalam mengimplementasikan sistem ekonomi sirkular. Program yang dapat dilakukan adalah dengan membentuk bank sampah pada setiap desa dan bank sampah induk dari Dinas Lingkungan Hidup dan Kehutanan, menerapkan konsep reduce-reuserecycle (3R) untuk setiap rumah tangga serta pendampingan dan pelatihan mengenai tata kelola sampah yang bertanggung jawab di setiap desa, sekolah dasar hingga SMA/SMK. Pentingnya keterlibatan para stakeholder dalam membentuk partisipasi masyarakat untuk menerapkan sistem ekonomi sirkular hingga masyarakat mampu secara mandiri.
\end{abstract}

Kata Kunci: Dinamika Sistem, Causal Loop Diagram, Ekonomi Sirkular, Pembangunan Berkelanjutan, Kelola Sampah

\section{PENDAHULUAN}

Kota Bengkayang merupakan daerah yang berdekatan dengan perbatasan Indonesia - Malaysia. Jumlah penduduk Kota Bengkayang merupakan tertinggi di kabupaten Bengkayang dengan 17 Kecamatan Kota. Dengan tingginya angka populasi tersebut meningkat pula tingkat konsumsi dan produksi masyarakat yang disebabkan karena peningkatan pendapatan daerah secara aggregate (PDRB), hal ini disebabkan karena Kota Bengkayang merupakan pusat perekonomian kabupaten Bengkayang. Selama periode tahun 2015 -2019 tumbuh dengan nilai rata-rata 3.57 persen dengan jumlah populasi sebanyak 34.723 jiwa pada tahun 2019 (Bappeda, 2020). Peningkatan jumlah konsumsi dan produksi tersebut menyebabkan adanya externalities negatif berupa limbah buangan masyarakat. Setiap tahun timbulan sampah tersebut terus meningkat, dengan penambahan sebesar 265 ton per tahun dari jumlah 37.172 ton pada tahun 2019 meningkat 37.438 ton pada tahun 2020 (IKLH, 2019).

Pada saat ini tata kelola sampah di Kota Bengkayang belum dilakukan secara optimal, sampah di TPA (Tempat Pemrosesan Akhir) dibiarkan begitu saja, tidak terdapat pegawai pemerintah yang mengurus TPA, kondisi sampah masih tercampur antara sampah organik dan anorganik, data terkait timbulan sampah tidak tersedia, akses menuju TPA masih sangat kurang, Industri pengolahan sampah tidak ada serta sarana dan prasarana masih sangat minim. Pentingnya partisipasi masyarakat dalam tata kelola sampah dan pendampingan yang berkelanjutan dalam mengubah paradigma terkait pemanfaatan sumber daya sampah menjadi produktif dalam mengurangi dampak negatif yang dihasilkan (Kristianto, 2020).

Jumlah timbulan sampah yang terus meningkat dan tidak terkelola dengan benar akan berdampak terhadap kualitas lingkungan hidup dan kesehatan masyarakat yang rendah. Pemerintah daerah perlu langkah preventif untuk mencegah terjadinya dampak buruk dari externalities negatif berupa limbah tersebut, dengan memberikan pengetahuan, pendampingan dan sosialisasi terkait dengan konsep mengurangi, menggunakan kembali dan mendaur ulang (Khairunisa $d k k$., 2020).

Pembangunan dengan memperhatikan unsur kualitas lingkungan hidup akan meningkatkan kesejahteraan secara inklusif bagi masyarakat dan lingkungan (Abdelaal and Sallam, 2019). Untuk mengendalikan jumlah sampah yang tidak terolah tersebut dapat dimulai dari tingkat rumah tangga dengan menggunakan pendekatan ekonomi sirkular. Ekonomi sirkular ini merupakan salah satu implementasi dari 
konsep ekonomi hijau untuk mencapai pembangunan berkelanjutan dengan berorientasi pada menyinergikan pertumbuhan ekonomi dan perlindungan lingkungan (Kasztelan, 2017).

Ekonomi sirkular pada prinsipnya berdasarkan pada konsep 3R (Reduce, Reuse Recycle) dengan tingkat produksi optimal dalam memanfaatkan sumber daya alam dengan meminimalkan eksploitasi alam, meminimalkan pencemaran lingkungan, mengurangi kadar emisi dan limbah dengan mengimplementasikan konsep yang berkelanjutan (Strielkowski, 2016). Model ekonomi sirkular merupakan model yang lebih baik dari model ekonomi linier (produksi - konsumsi - disposal) dengan tujuan untuk mengoptimalkan dan memaksimalkan potensi dari setiap material serta dapat memulihkan material yang telah sampai pada usia akhir dengan inovasi teknologi yang ramah lingkungan (Marino and Pariso, 2016).

Konsep ekonomi sirkular dapat meminimalkan tingkat timbulan sampah yang dihasilkan dengan adanya desain produk baru yang ramah lingkungan dengan proses yang cermat pada setiap industri dalam mengimplementasikan metode close loop system (De Angelis and De Angelis, 2018). Dalam jangka panjang, produksi sumber daya dari limbah buangan dapat mengurangi emisi hingga $70 \%$, meningkatkan jumlah tenaga kerja sebesar $4 \%$, dan dapat mereduksi limbah dalam jumlah yang cukup besar (Stahel, 2016). Implementasi ekonomi sirkular dapat meningkatkan ketahanan lingkungan, kesejahteraan sosial masyarakat, mengurangi kerusakan lingkungan, meningkatkan pembentukan new product added value sekaligus dapat meningkatkan pertumbuhan ekonomi hijau yang searah dengan tujuan pembangunan berkelanjutan (Lakshmi, Aruna Devi and Jhansi Rani, 2020).

Pertumbuhan ekonomi yang berprinsip pada ketahanan lingkungan dapat memberikan kontribusi pada aspek investasi dan dinamisme yang diperlukan untuk menyebarkan dan mengembangkan teknologi baru, yang merupakan dasar untuk mengelola aset lingkungan dan pertumbuhan produktivitas (Busu and Trica, 2019). Penerapan konsep ekonomi sirkular dengan pendekatan variabel timbunan sampah Kota per kapita, tingkat daur ulang sampah Kota, tingkat daur ulang limbah kemasan menurut jenis kemasan, tingkat daur ulang limbah organik, dan tingkat daur ulang limbah elektronik dapat meningkatkan pertumbuhan ekonomi berkualitas keberlanjutan dan pertumbuhan PDB secara inklusif sekaligus mengurangi penggunaan sumber daya alam dan memastikan perlindungan lingkungan yang lebih besar (Grdic, Nizic and Rudan, 2020).

Indikator yang dapat diukur terkait implementasi ekonomi sirkular secara ekonomi regional / makro adalah dengan menggunakan tingkat PDRB sebagai data dasar, indikator pembangunan ekonomi menggunakan tingkat pertumbuhan ekonomi daerah. Indeks tingkat ekonomi sirkular dengan jumlah timbulan sampah, jumlah tingkat daur ulang, jumlah kapasitas limbah buangan di TPA dan tingkat beban emisi yang dihasilkan. Indikator perlindungan ekologi mengacu pada tingkat kualitas lingkungan hidup, kinerja lingkungan, konstruksi ekologi dan potensi perbaikan lingkungan ekologi dan kondisi lingkungan lainnya. Indikator manajemen hijau mengacu pada kebijakan yang terapkan dan aturan manajemen pemerintah daerah untuk mendorong pembangunan ekonomi sirkular dan indikator manajemen perusahaan serta kesadaran masyarkat akan sampah (Mao $d k k$. 2018).

Hasil penelitian yang dilakukan oleh Ghisellini dan Ulgiati (2020) bahwa sistem ekonomi sirkular yang dilakukan di beberapa perusahaan di Italia, model bisnis yang didasarkan pada investasi berkelanjutan dalam eco-innovation dalam lingkungan hidup dapat memberikan keuntungan dan manfaat jangka panjang karena sampah menjadi sumber daya yang berharga. Hal ini didasarkan karena kelangkaan sumber daya alam, distribusi geografis yang tidak simetris dan memburuknya masalah lingkungan. Jika hal ini dapat diimplementasikan di tingkat daerah maka tingkat investasi akan menjadi meningkat diikuti oleh peningkatan pertumbuhan ekonomi daerah dan dalam jangka panjang dapat mengurangi kerusakan lingkungan, pengangguran dan kemiskinan (Ghisellini, Cialani and Ulgiati, 2016).

Sistem ekonomi sirkular menekankan pada produktivitas limbah dan cara pemulihan. Pengelolaan sampah memerlukan perubahan signifikan dalam struktur sistem pengelolaan sampah yang dapat menimbulkan masalah baru, salah satunya adalah peningkatan biaya externalities bagi masyarakat. Perlu memahami siklus limbah masyarakat sebelum mengambil sebuah kebijakan, hal ini disebabkan karena fasilitas pengelolaan sampah dibangun dengan menggunakan dana publik dalam menyediakan layanan publik kepada masyarakat. Pemulihan sumber daya limbah dalam jangka panjang menghasilkan pendapatan yang tinggi karena dapat meningkatkan investasi industri pengelolaan sampah (Tomić and Schneider, 2020).

Penelitian ini akan mengidentifikasi fenomena permasalahan tata kelola sampah dalam penerapan sistem ekonomi sirkular berbasis masyarakat dengan model yang akan dijelaskan dengan pendekatan Causal Loop Diagram. Dengan solusi yang ditawarkan adalah model kebijakan pengelolaan sampah berbasis masyarakat yang bertumpu pada permasalahan yang terjadi di dalam masyarakat, dengan pemanfaatan sampah menjadi produk bernilai manfaat dan ekonomis.

\section{RUANG LINGKUP}

Ekonomi sirkular merupakan pengembangan dari konsep ekonomi linier dalam masyarakat. Perbedaannya adalah konsep ekonomi linier membeli, menggunakan dan membuang dengan memperhatikan unsur 
externalities (limbah/ sampah) dalam sebuah harga yang dikeluarkan yang menimbulkan biaya ekonomi, sosial dan lingkungan, sedangkan konsep ekonomi sirkular adalah regenerasi sistem secara alami mulai dari proses produksi, untuk menghasilkan perubahan secara sistemis secara komprehensif dalam aktivitas ekonomi. Konsep ekonomi sirkular ini dapat membangun ketahanan sebuah produk yang dihasilkan untuk waktu yang panjang.

Konsep ekonomi sirkular dapat menciptakan bisnis dan aktivitas ekonomi yang lebih baik dan bermanfaat bagi aspek lingkungan hidup dan aspek sosial dalam masyarakat. Penerapan konsep ini memerlukan investasi yang cukup besar dan waktu yang cukup panjang dalam mengubah konsep ekonomi linier ke ekonomi sirkular, namun konsep ekonomi sirkular untuk masa mendatang dapat memberikan manfaat dalam mencapai pembangunan berkelanjutan.

Penelitian ini bertujuan untuk mengidentifikasi permasalahan tata kelola sampah di Kota Bengkayang dengan cakupan masalahnya adalah kurangnya kemudahan akses dan sarana - prasarana masyarakat untuk membuang sampah, sampah rumah tangga masih dalam keadaan dicampur dan dibakar, minimnya industri daur ulang dan minimnya sosialisasi dan pendampingan pada masyarakat. Batasan penelitian hanya berfokus pada tata kelola sampah dan implementasi ekonomi sirkular berbasis masyarakat. Hasil penelitian adalah model kebijakan tata kelola sampah berkelanjutan menjadi barang produktif bernilai manfaat dan ekonomis yang menyesuaikan kondisi sosial dan ekonomi masyarakat Kota Bengkayang, penyelesaian masalah ini tidak dapat digeneralisasikan, hal ini mencakup kondisi sosial, ekonomi dan demografi yang berbeda untuk tiap daerah / kabupaten.

\section{BAHAN DAN METODE}

Penelitian ini menggunakan metode kualitatif Dinamika Sistem (System Dynamics) dengan alat yang dipergunakan untuk menjelaskan menggunakan Causal Loop Diagram. Sumber data terdiri dari 3 basis data yaitu : Mental data (observation experience), Written data dan numeric data. Analisis data dengan metode triangulasi: Wawancara, observasi dan dokumentasi. Dengan teknik pemilihan objek secara purposefully select dimana peneliti langsung mengidentifikasi sumber informasi individu / kelompok secara terencana dan sengaja (Creswell, 2014). Data mental dilakukan dengan cara wawancara mendalam, dipilih berdasarkan kompetensi informan yang terdiri dari pemerintah daerah dinas lingkungan hidup terdiri dari 3 informan, masyarakat umum terdiri dari 5 informan, tokoh masyarakat terdiri dari 3 informan, pengusaha terdiri dari 5 informan, pemuda terdiri dari 5 informan. Observasi dilakukan di lokasi TPS, TPA, beberapa pemukiman masyarakat dan cek lokasi aliran sungai serta lahan pada masyarakat yang biasanya digunakan untuk membakar sampah. Dokumentasi dilakukan dengan mengambil beberapa foto kondisi lapangan, dalam hal ini peneliti memberikan pertanyaan berbeda namun relevan dengan tema penelitian, hal ini dilakukan karena hasil wawancara pertama berbeda dengan apa yang disampaikan di lapangan dengan laporan yang ada.

Metode dinamika sistem (system dynamics) merupakan sebuah metode pemodelan yang penerapannya erat berhubungan dengan pertanyaan tentang dinamika sebuah beberapa tendensi dalam beberapa sistem yang kompleks, yaitu pola tingkah laku yang dibangkitkan oleh sistem itu dengan bertambahnya waktu, metode ini diperkenalkan pada tahun 1950-an oleh Jay W Foresster (Sterman, 2002). Model yang dibuat berdasarkan pada keadaan di dunia nyata yang disederhanakan, berupa objek, situasi atau proses dari sistem yang kompleks dan mempunyai hubungan kausalitas (Forrester, 2009).

Pendekatan Causal Loop Diagram (CLD) menyatakan hubungan sebab akibat diantara sekumpulan unsur yang berjalan di dalam sistem. Elemen dasar CLD terdiri atas variabel (faktor) dan panah (links). Variabel merupakan kondisi, situasi, aksi, atau keputusan yang mempengaruhi dan dapat dipengaruhi oleh variabel lainnya. Variabel dapat berbentuk kuantitatif (dapat terukur) dan kualitatif (Kim and Andersen, 2012). Metode ini bermanfaat untuk menjelaskan interdependensi dalam berbagai situasi dan efektif untuk mengetahui mental models. Hubungan sebab akibat antar variabel ini menunjukkan dua kemungkinan yang terjadi yaitu: kemungkinan hubungan tersebut bergerak ke arah yang sama $(+/ \mathrm{R}=$ Reinforcing) atau bergerak ke arah yang berlawanan (- / $\mathrm{B}=$ Balancing).

Ekonomi sirkular merupakan sebuah konsep yang diterapkan untuk menciptakan tata kelola sampah yang berkelanjutan dengan memanfaatkan sumber sampah menjadi produk bernilai manfaat dan ekonomis. Konsep ini juga dapat memberikan peluang usaha berbasis daur ulang yang pada akhirnya dapat meningkatkan peluang kerja, investasi, pertumbuhan ekonomi, mengurangi kemiskinan dan meningkatkan pendapatan daerah. Hal ini dapat dilihat pada gambar 1 dalam kerangka pemikiran konseptual penelitian. 


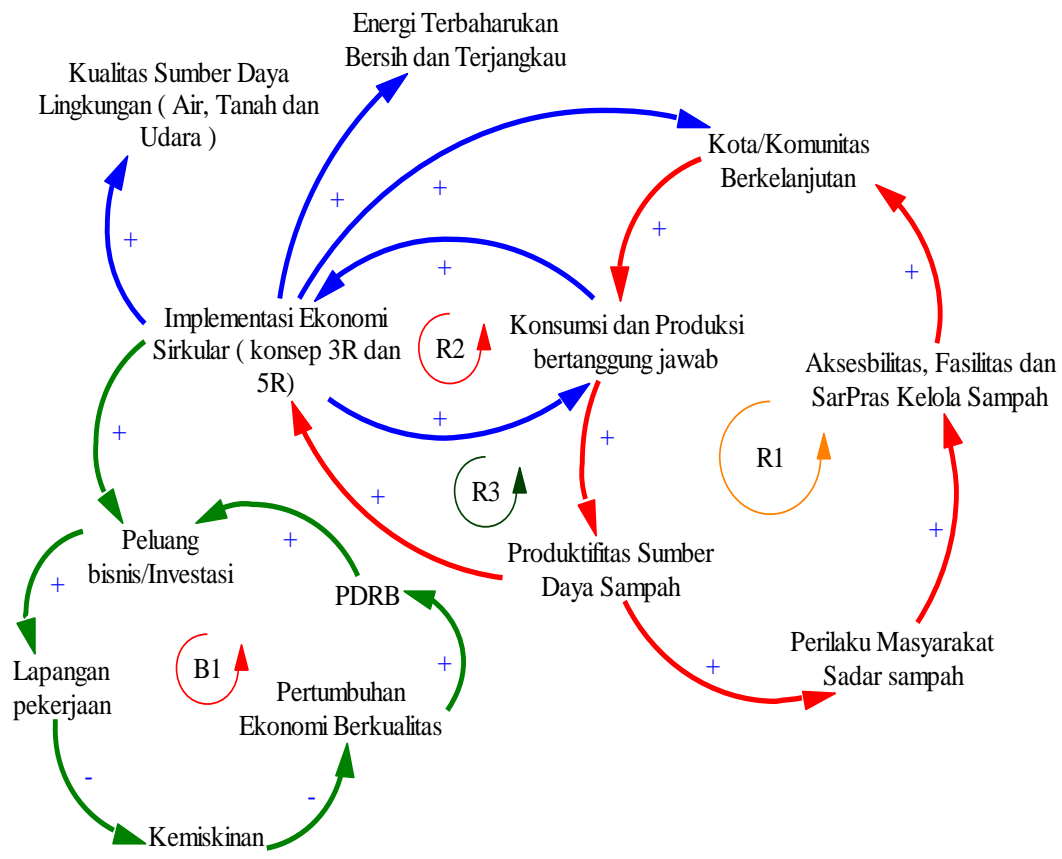

Gambar 1. Kerangka Pemikiran Konseptual Penelitian

\section{PEMBAHASAN}

Dalam mengimplementasikan ekonomi sirkular diperlukan proses yang cukup panjang. Penyusunan sebuah kebijakan terkait hal ini perlu dikaji dan diidentifikasi permasalahan apa yang terjadi dalam dinamika masyarakat secara holistik dan pentingnya keterlibatan masyarakat dalam menyusun kebijakan tersebut. Dalam pembahasan ini akan dijelaskan permasalahan yang terkait dan model kebijakan yang ditawarkan.

\subsection{Permasalahan Tata Kelola Sampah}

Ada beberapa permasalahan yang terjadi terkait kondisi tata kelola sampah di Kota Bengkayang yakni menyangkut masalah aksesibilitas, fasilitas dan sarana prasarana; perilaku masyarakat dalam mengelola sampah; tidak adanya industri/pusat daur ulang serta minimnya intervensi pemerintah dan swasta dalam tata kelola sampah.

Permasalahan yang dihadapi masyarakat Kota Bengkayang terkait dengan aksesibilitas, fasilitas dan sarana prasarana dalam hal membuang sampah adalah:

1. Setiap desa yang terdiri dari beberapa dusun tidak tersedia TPS (Tempat Pembuangan Sementara) yang memadai

2. Tidak terdapat tempat sampah baik tempat sampah organik dan sampah anorganik

3. Kurangnya petugas kebersihan yang bertugas untuk mengakses ke desa / dusun

4. Masyarakat membuang secara mandiri ke TPS yang terdiri dari 4 TPS di seluruh Kota
Bengkayang dengan jumlah penduduk yang cukup tinggi yaitu sebesar 34.723 jiwa

5. Infrastruktur jalan menuju ke masyarakat masih kurang memadai, banyak jalan yang rusak

6. Minimnya kendaraan pengangkut sampah baik truk angkut besar atau kendaraan kecil pengangkut sampah ke TPS. Hal ini dapat dilihat dari CLD R1 dalam kerangka pemikiran bahwa aksesibilitas, fasilitas dan sarana prasarana yang tersedia sebagaimana mestinya maka Kota/daerah/komunitas daerah yang berkelanjutan tersebut akan meningkat, begitu pula sebaliknya jika minimnya akses, fasilitas dan sarana prasarana minim maka rendah juga Kota/komunitas yang berkelanjutan.

Perilaku masyarakat Kota Bengkayang saat ini dari membuang sampah adalah dibakar, dicampur, ditimbun dan dibuang di pinggir sungai hal ini disebabkan karena minimnya pengetahuan masyarakat mengenai tata kelola sampah yang dapat dimanfaatkan menjadi produk bernilai manfaat dan ekonomi. Masih minimnya masyarakat terkait konsep $3 R$ (ReduceReuse Recycle) bahkan konsep $5 R$ (Reduce-ReusedRecycle-Recovery-Repair) dalam menerapkan pendekatan ekonomi sirkular berbasis masyarakat. Perilaku ini terjadi disebabkan karena minimnya akses, fasilitas dan sarana prasarana, yang membuat masyarakat enggan untuk mengelola sampah.

Tidak terdapat industri/pusat daur ulang yang berada di Kota Bengkayang hal ini menyebabkan sampah yang dapat di daur ulang tidak dapat dimanfaatkan dengan baik. Masih tidak adanya proyek percontohan di TPA mengenai industri daur ulang untuk sampah anorganik dan industri 
percontohan daur ulang untuk sampah organik. Berdasarkan data dari SIPSN (Sistem Informasi Pengelolaan Sampah Nasional) Kementerian Lingkungan Hidup dan Kehutanan, untuk Kalimantan Barat per kabupaten jumlah Pusat Daur Ulang (PDU) pada tahun 2020 hanya terdapat di Kota Singkawang sejumlah 2 lokasi. Dengan jumlah sampah terkelola pada lokasi pertama sejumlah 0,73 ton/tahun dan lokasi kedua sejumlah 19,35 ton/tahun di Kota Singkawang, sedangkan data Kota Bengkayang tidak ada. Hal ini dapat dilihat pada gambar 2 perihal data Pusat Daur Ulang di Kalimantan Barat.

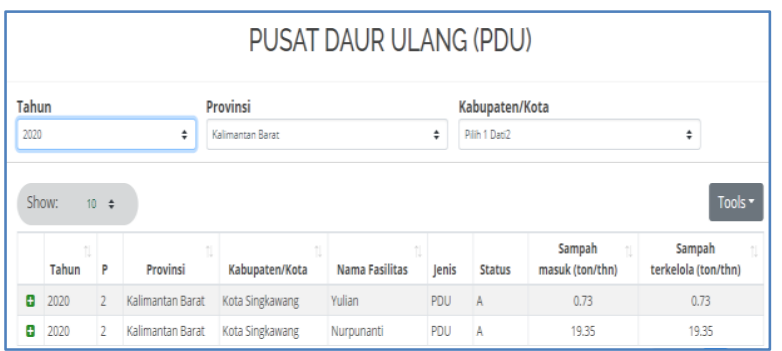

Gambar 2. Pusat Daur Ulang Kalimantan Barat

Saat ini intervensi pemerintah daerah dan perusahaan swasta masih sangat minim hal ini digambarkan dengan masih minimnya tenaga kerja yang bertugas untuk mengelola sampah di TPA, pemerintah daerah belum maksimal menyediakan fasilitas di tempat - tempat yang menunjukkan aktivitas masyarakat seperti di pasar, terminal dan sarana publik. Gambar 3 adalah kondisi akses dan TPA (Tempat Pemrosesan Akhir) Kota Bengkayang:
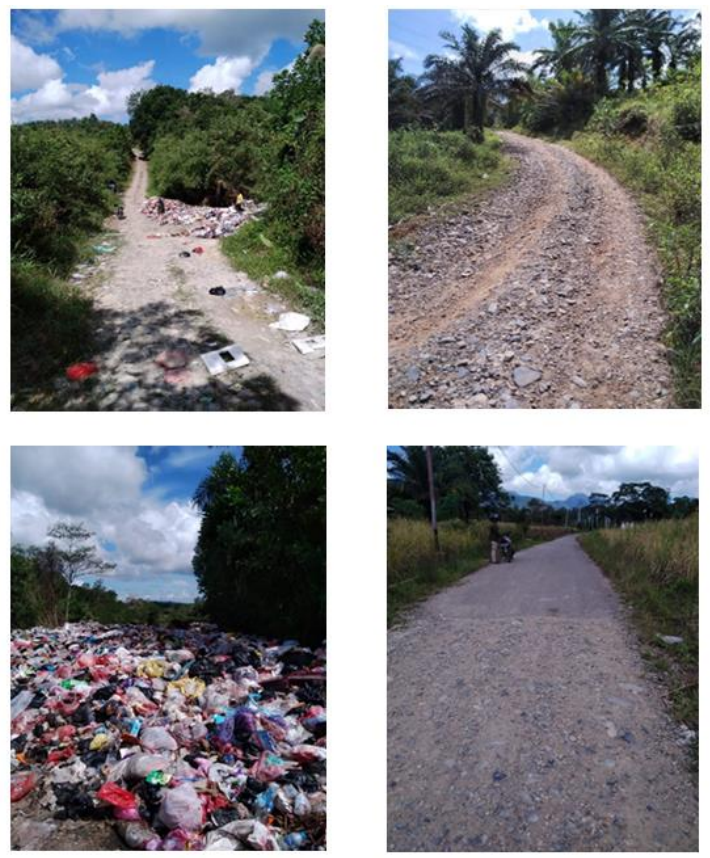

Gambar 3. Kondisi akses dan lokasi TPA Kota Bengkayang

\subsection{Model Kebijakan}

Dalam mengimplementasikan ekonomi sirkular di Kota Bengkayang perlu adanya kolaborasi antar stakeholder (pemerintah daerah, masyarakat umum, wirausaha, aktivitas lingkungan dan akademisi) demi proses pembangunan berkelanjutan daerah yang lebih baik. Pada Gambar 4 menjelaskan model kebijakan yang diilustrasikan dalam Causal Loop Diagram (CLD) adalah :

1. Dalam CLD-B1 dijelaskan bahwa tingginya tingkat sampah yang tidak terkelola disebabkan karena rendahnya kesadaran masyarakat dalam mengelola sampah yang benar dan perlu di terapkan reward and punishment bagi warga yang berhasil mengelola sampah rumah tangga dengan benar, serta pendekatan hukum adat (local wisdom) dan hukum formal jika ada warga yang masih berperilaku membuang sampah sembarangan. Pendekatan yang masif terkait partisipasi masyarakat agar terlibat dan bertanggung jawab terhadap hasil limbah yang diproduksi setiap rumah tangga. Peningkatan pendampingan dan pelatihan secara berkesinambungan dengan program kerja sederhana seperti pengompasan, pemanfaatan limbah buah dan sayur menjadi eco enzyme yang hasilnya dapat dipergunakan sendiri ataupun dapat diperjualbelikan dan pembuatan biopori pada setiap rumah tangga yang bertujuan untuk mengomposkan dan penyerapan air hujan (Elamin $d k k ., 2018$ ). Hal ini perlu dilakukan mengingat bahwa tata kelola sampah yang buruk akan berdampak terhadap kualitas lingkungan hidup (air, tanah dan udara). Manfaat bagi masyarakat adalah dalam penetapan harga baru sumber daya yang langka, seperti air atau udara yang lebih bersih, memiliki nilai bagi mereka yang lebih besar daripada biaya peningkatan pembayaran untuk layanan publik (atau untuk barang pribadi yang biaya lebih tinggi untuk internalizes externalities lebih besar daripada biayanya). Dalam jangka panjang memberikan manfaat potensial namun dalam jangka pendek dapat mengurangi pendapatan riil (Dercon, 2014). Pentingnya partisipasi masyarakat untuk mengurangi distribusi sampah ke TPS (Tempat Pembuangan Sementara) yang bertujuan untuk menghasilkan zero waste ke TPA (Tempat Pemrosesan Akhir). Memperhatikan unsur mata pelajaran / kuliah di tingkat pendidikan dari Sekolah dasar hingga Perguruan Tinggi.

2. Dalam CLD B1-R2 dijelaskan bahwa pentingnya kerja sama secara berkesinambungan untuk melakukan pendampingan dan pelatihan bagi masyarakat terkait tata kelola sampah yang benar dan sosialisasi mengenai dampak lingkungan yang ditimbulkan dari tata kelola sampah yang keliru. Kerja sama yang dilakukan terkait 
bagaimana memanfaatkan sampah rumah tangga (organik dan anorganik) menjadi produk baru bernilai manfaat dan ekonomis. Pengembangan konsep SBM (Sustainable Business Model) yaitu sebuah konsep bisnis dalam menciptakan produk barang dan jasa yang mementingkan aspek sosial dan lingkungan, pada segmen UMKM secara sederhana dengan membeli kembali limbah hasil produksi kepada konsumen (Evans $d k k$., 2017). Memberikan pendampingan dan pelatihan bagi UMKM untuk menghasilkan produk yang ramah lingkungan dengan meminimalkan penggunaan bahan-bahan yang berbahaya untuk lingkungan dan kesehatan dengan mengimplementasikan green production. Untuk segmen produk rumah tangga dengan membuat desain produk yang selalu dapat ditingkatkan secara efisien terhadap energi dan biaya dengan model yang baru.

3. Dalam CLD B1 dijelaskan bahwa mendirikan bank sampah pada setiap desa sebagai bank sampah unit dan bank sampah induk di TPA sebagai pusat kegiatan bank sampah unit di Kota Bengkayang. Bank sampah ini di buat untuk memfasilitasi masyarakat untuk menjual / membeli produk yang dihasilkan dari sumber daya sampah, seperti: pupuk cair organik, hand sanitizer, eco bricks, kerajinan tangan dan produk lain yang bermanfaat dari hasil sampah di masyarakat. Produk tersebut dapat ditukarkan oleh masyarakat ke produsen dengan membeli kembali limbah buangan konsumen. Dari sistem product life extension ini secara finansial dan loyalitas dapat selalu terjaga dan menarik karena produsen mendapat sumber daya yang murah dari pelanggan dan pelanggan mendapat pendapatan tambahan dari produk bekas yang mereka jual ke konsumen (Lacy and Rutqvist, 2015). Pelarangan praktik open dumping kepada masyarakat untuk membuang sampah di TPA, hal ini dilakukan untuk menjaga kualitas lokasi TPA setempat (Popli, Sudibya and Kim, 2017).

4. Dalam CLD R2 dijelaskan perlunya pengembangan teknologi digital dan / atau teknologi pengolahan daur ulang yang ramah lingkungan yang dapat membantu dalam proses tata kelola sampah berkelanjutan. Dengan teknologi yang tepat guna maka tidak berhenti kepada daur ulang saja namun lebih kepada regenerasi sebuah produk, hal ini akan meningkatkan sektor konstruksi daerah dengan tetap melibatkan berbagai pemangku kepentingan (Gupta, 2019). Teknologi digital dari pemerintah daerah yang masuk bagian dari $E$ - government, yang dapat diterapkan dengan membeli sampah dari masyarakat untuk diolah menjadi bermanfaat bagi masyarakat yang enggan untuk mengolah sampah mereka dengan persyaratan sampah sudah dipilih dan dipilah dengan benar. Dengan bantuan teknologi dengan sistem layanan sebuah produk, big data dan data integrasi secara komprehensif. Teknologi digital memainkan peran penting dalam transisi menuju ekonomi Sirkular dengan mengoptimalkan aliran material maju dan memungkinkan aliran material balik. Dalam hal ini, ekonomi sirkular mengikuti lintasan yang sama dengan sistem pelayanan produk (Product Services System / PSS) dan ekosistem layanan secara umum, hal ini bertujuan sebagai kontrol dan pengendalian arus sampah di masyarakat (Pagoropoulos, Pigosso and McAloone, 2017).

5. Dalam CLD R2 terkait tinggi peluang bisnis sebaiknya dibarengi dengan kemudahan dalam birokrasi yang dapat meningkatkan iklim investasi hijau. Efisiensi birokrasi yang bertujuan untuk memberi kemudahan bagi investor yang hendak menanamkan modalnya untuk usaha yang berbasis keramahan lingkungan dengan catatan pemerintah selalu kontrol kegiatan usaha dengan melakukan AMDAL dan sertifikasi bagi investor yang layak untuk menanamkan modalnya. Penerapan CSR (Corporate Social Responsibility) yang benar untuk kemanfaatan bagi masyarakat dan lingkungan sekitar (Babader dkk., 2016). Pembuat kebijakan, dalam hal ini pemerintah memiliki peran kunci dalam menerapkannya, misalnya dengan: menghilangkan barang-barang plastik yang tidak perlu dan bermasalah di seluruh perekonomian, merangsang inovasi, memfasilitasi sistem pengumpulan untuk daur ulang dan pendanaan yang stabil dan berulang yang diperlukan, dan memberi insentif peningkatan penggunaan bahan daur ulang. Inisiatif kebijakan dan kepemimpinan seperti itu sangat penting untuk membantu mengukur transisi di semua sektor. Pembuat kebijakan dapat memanfaatkan peluang untuk membantu investor / industri hijau dalam membuat mekanisme penciptaan nilai baru dan menuntut pengaturan ulang sistem (MacArthur, 2021).

6. Dalam CLD B4 dan B3 dijelaskan bahwa, terkait masalah timbulan sampah dengan meningkatnya pendapatan per kapita masyarakat yang diikuti dengan peningkatan populasi masyarakat Bengkayang, maka meningkat pula timbulan sampah per kapita. Semakin banyaknya sampah masuk ke TPS per hari perlu pembenahan dalam infrastruktur, sarana prasarana dan fasilitas, jika memungkinkan penambahan armada pengangkutan yang lebih baik. 


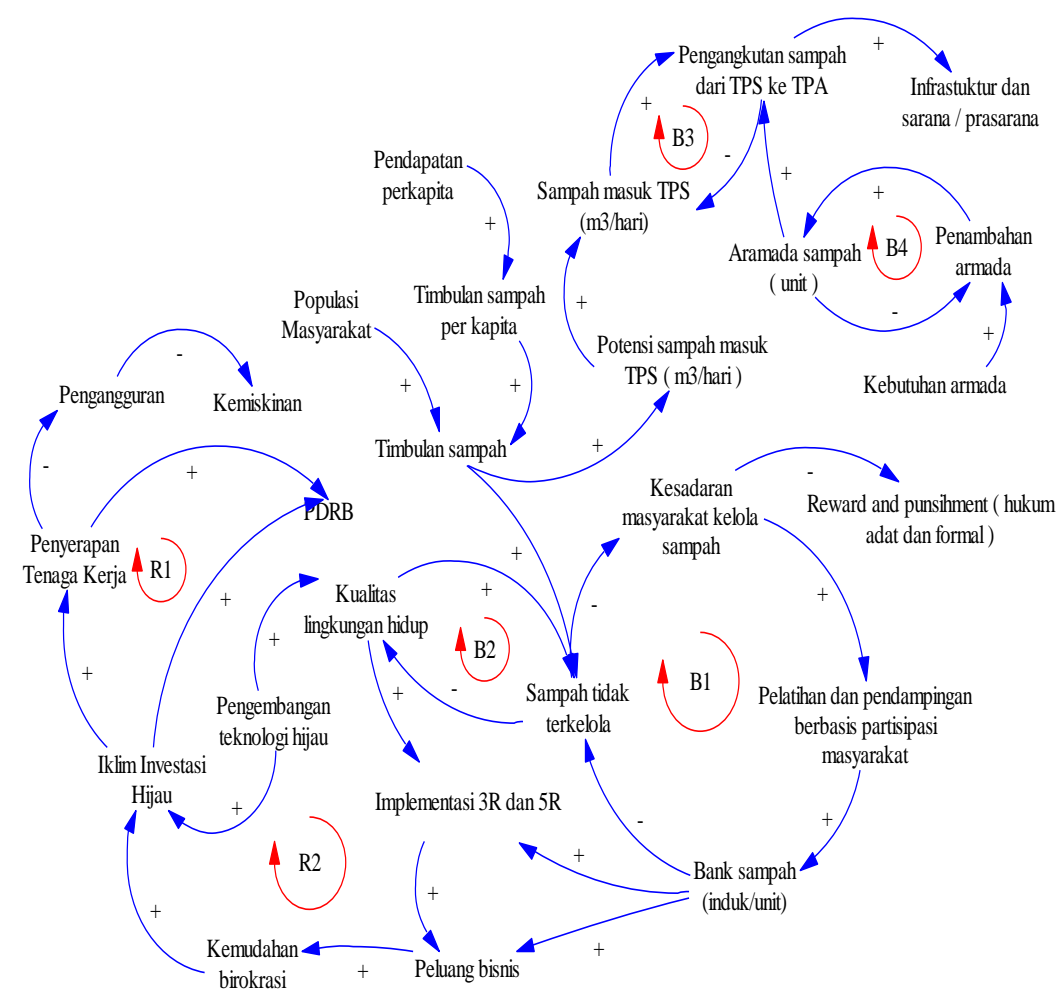

Gambar 4. Model Kebijakan Ekonomi Sirkular Kota Bengkayang

\section{KESIMPULAN}

Perlunya tanggung jawab yang berkelanjutan dengan penambahan dan perbaikan fasilitas, aksesibilitas dan sarana prasarana. Pendampingan dan pelatihan kepada masyarakat luas mengenai tata kelola sampah yang benar. Perlunya investasi industri/pusat daur ulang. Kolaborasi dalam kerja sama penanganan sampah Kota dengan pihak swasta terutama dengan pemanfaatan teknologi tepat guna dan digitalisasi. Kontribusi terhadap perekonomian daerah dan lingkungan hidup adalah menciptakan efisiensi dan efektifitas birokrasi perizinan untuk meningkatkan investasi hijau dari industri daur ulang, penyerapan tenaga kerja di daerah dalam mengurangi kemiskinan., mendirikan bank sampah induk tingkat daerah / kabupaten dan memfasilitasi tiap desa dengan bank sampah desa yang bertujuan untuk merangsang masyarakat agar peduli terhadap sampah rumah tangga, peningkatan efisiensi dan sistem transportasi sampah pada masyarakat dengan cakupan yang lebih luas serta meninjau kembali sistem yang hemat biaya, merangsang investasi industri daur ulang dan potensi usaha yang pada akhirnya akan dapat mengurangi jumlah pengangguran dan menekan angka kemiskinan, meningkatkan kualitas kesehatan masyarakat dan kualitas lingkungan hidup

\section{SARAN}

Saran untuk penelitian dengan topik yang lebih komprehensif yang mengidentifikasikan hubungannya dengan konsep Tujuan Pembangunan Berkelanjutan (TPB) yang saling terkait dengan 4 aspek dasarnya yaitu Aspek ekonomi, aspek sosial, aspek lingkungan dan aspek tata kelola dan hukum. Penerapan ekonomi sirkular memerlukan waktu, pemikiran dan konsep yang matang dan permasalahan yang sangat dinamis dalam masyarakat, maka perlu adanya controlling dan supervisi yang berkelanjutan. Kontribusi ekonomi sirkular untuk pertumbuhan ekonomi berkualitas dalam jangka panjang sangat besar, maka perlu dipersiapkan dari sekarang sebagai langkah preventif.

\section{DAFTAR PUSTAKA}

Abdelaal, M. R. M. and Sallam, I. (2019) 'Green Economy Themes: Pathway to Sustainable Urban Development', The Academic Research Community publication, 3(2), p. 48. doi: 10.21625/archive.v3i2.501.

De Angelis, R. and De Angelis, R. (2018) Sustainable Development, Corporate Sustainability and the Circular Economy, Business Models in the Circular Economy. doi: 10.1007/978-3-31975127-6_2.

Babader, A. $d k k$. (2016) 'A system dynamics approach for enhancing social behaviours regarding the reuse of packaging', Expert Systems with Applications, 46, pp. 417-425. doi: 10.1016/j.eswa.2015.10.025.

Bappeda (2020) 'Profil dan Analisis Pembangunan 
Daerah Kabupaten Bengkayang', in Bappeda Bengkayang.

Busu, M. and Trica, C. L. (2019) 'Sustainability of Circular Economy Indicators and Their Impact on Economic Growth of the European Union', Sustainability (Switzerland). doi: doi:10.3390/su11195481.

Creswell (2014) Research Design: qualitative, quantitative and mixec methods approaches. SAGE Publications Inc.

Dercon, S. (2014) 'Is Green Growth Good for the Poor?', The World Bank Research Observer, 29(2), pp. 163-185. doi: 10.1093/wbro/lku007.

Elamin, M. Z. dkk. (2018) 'Analisis Pengelolaan Sampah pada Masyarakat Desa Disanah Kecamatan Sreseh Kabupaten Sampang', Jurnal Kesehatan Lingkungan, 10(4), p. 368. doi: 10.20473/jkl.v10i4.2018.368-375.

Evans, S. $d k k$. (2017) 'Business Model Innovation for Sustainability: Towards a Unified Perspective for Creation of Sustainable Business Models', Business Strategy and the Environment, 26(5), pp. 597-608. doi: 10.1002/bse.1939.

Forrester, J. (2009) 'Some basic concepts in system dynamics', Sloan School of Management, Massachusetts Institute of Technology, pp. 117. Available at: http://www.systemsmodelbook.org/uploadedfil e/238_63f73156-02df-4d87-b0c6-

c286a7beec26_SomeBasicConcepts.pdf.

Ghisellini, P., Cialani, C. and Ulgiati, S. (2016) 'A review on circular economy: The expected transition to a balanced interplay of environmental and economic systems', Journal of Cleaner Production, 114. doi: 10.1016/j.jclepro.2015.09.007.

Ghisellini, P. and Ulgiati, S. (2020) 'Circular economy transition in Italy. Achievements, perspectives and constraints', Journal of Cleaner Production, 243, p. 118360. doi: 10.1016/j.jclepro.2019.118360.

Grdic, Z. S., Nizic, M. K. and Rudan, E. (2020) 'Circular economy concept in the context of economic development in EU countries', Sustainability (Switzerland), 12(7). doi: 10.3390/su12073060.

Gupta, S. (2019) 'Barriers and Opportunities in Circular Economy in the Construction Industry in India', Global Research and Development Journal for Engineering, 4(7), pp. 22-27.

IKLH (2019) 'Indeks Kualitas Lingkungan Hidup 2019', in IKLH 2019.

Kasztelan, A. (2017) 'Green growth, green economy and sustainable development: Terminological and relational discourse', Prague Economic Papers, 26(4), pp. 487-499. doi: $10.18267 /$ j.pep.626.

Khairunisa, N. S. $d k k$. (2020) 'Integrasi Data Sampah
Sebagai Upaya Mewujudkan Zero Waste Management: Studi Kasus Di Kota Bandung', Jurnal Analisa Sosiologi, pp. 108-123.

Kim, H. and Andersen, D. F. (2012) 'Building confidence in causal maps generated from purposive text data: Mapping transcripts of the Federal Reserve', System Dynamics Review, 28(4), pp. 311-328. doi: 10.1002/sdr.1480.

Kristianto, A. H. (2020) 'Implementasi Circular Economy 3R Model dan Literasi Keuangan Metode Participatory Learning Action Daerah 3T', CARADDE: Jurnal Pengabdian Kepada Masyarakat, 3(2). doi: doi.org/10.31960/caradde.v3i2.498.

Lacy, P. and Rutqvist, J. (2015) 'waste to wealth: the circular economy advantage', in palgrave macmillan. palgrave macmillan. doi: 10.1057/9781137530707.

Lakshmi, V. V., Aruna Devi, D. and Jhansi Rani, K. P. (2020) Wealth from Poultry Waste, Waste Management as Economic Industry Towards Circular Economy. doi: 10.1007/978-981-151620-7_7.

MacArthur, E. (2021) 'Universal circular economy policy goals', in Ellen MacArthur Foundation. Ellen Macarthur Foundation.

Mao, J. dkk. (2018) 'Circular Economy and Sustainable Development Enterprises', Circular Economy and Sustainable Development Enterprises, pp. 151-170. doi: 10.1007/978-981-10-8524-6.

Marino, A. and Pariso, P. (2016) 'From linear economy to circular economy: research agenda', International Journal of Research in Economics and Social Sciences, 6225(6), pp. 2249-7382. Available at: http://www.euroasiapub.org.

Pagoropoulos, A., Pigosso, D. C. A. and McAloone, T. C. (2017) 'The Emergent Role of Digital Technologies in the Circular Economy: A Review', Procedia CIRP, 64, pp. 19-24. doi: 10.1016/j.procir.2017.02.047.

Popli, K., Sudibya, G. L. and Kim, S. (2017) 'A Review of Solid Waste Management using System Dynamics Modeling', Journal of Environmental Science International, 26(10), pp. 1185-1200. doi: 10.5322/jesi.2017.26.10.1185.

Stahel, W. R. (2016) 'The circular economy', Nature, 531(7595), pp. 435-438. doi: $10.1038 / 531435 \mathrm{a}$.

Sterman, J. D. (2002) 'All models are wrong: Reflections on becoming a systems scientist', System Dynamics Review, 18(4), pp. 501-531. doi: $10.1002 /$ sdr.261.

Strielkowski, W. (2016) 'Entrepreneurship, sustainability, and Solar Distributed Generation', The International Journal 
Entrepreneurship And Sustainability Issues, 4(3), pp. 102-103. doi: 10.1027/02275910.16.3.102.

Tomić, T. and Schneider, D. R. (2020) 'Circular economy in waste management - Socioeconomic effect of changes in waste management system structure', Journal of Environmental Management, 267(December 2019). doi: 10.1016/j.jenvman.2020.110564. 